\title{
The Effect of Chemical Pretreatment on the Quality of Dehydrated Pigeonpeas
}

\author{
Abdul R. Rahman 1
}

\section{INTRODUCTION}

Dehydration is the oldest method of food preservation, yet it is still practiced for specific foods on a wide commercial scale. Therefore, dehydrated foods are considered to be acceptable to the public. High-quality dehydrated food would effect considerable savings in shipping weight, space, and the amount of tinplate now needed for canned products. There would also be savings in cold storage as required for frozen foods. Any dehydrated food to be acceptable must, when reconstituted, possess a desirable appearance, texture, and flavor, and a satisfactory rehydration ratio.

Pigeonpeas do not mature uniformly on the vine, hence inmature, fully mature, and dried peas can all be obtained at the same time, and from the same tree. However, off-grade green pigeonpeas are obtained in each picking during the harvest season, and since they have limited use, a method of preserving them should be developed. The development of a successful method for the dehydration of green pigeonpeas might help in solving some of the problems, specially the expenses of the labor involved in handpicking and grading the peas.

Pigeonpeas possess a relatively thick seedcoat which retards the evaporation of moisture during dehydration and water absorption during rehydration. This suggests the application of chemical or mechanical pretreatment which merely affects the skin in order to permit an easier and better evaporation of moisture during dehydration and better water absorption during rehydration.

\section{REVIEW OF LITERATURE}

No investigations on the dehydration of pigeonpeas are reported in the literature though numerous publications on the dehydration of other fruits and vegetables are available. No work on the dehydration of pigeonpeas has been done in Puerto Rico, but intensive research on the canning of this crop is being conducted by Sánchez-Nieva $(1)^{2}$ of the Food Technology

1 Associate Food Technologist, Food Technology Laboratory, Agricultural Experiment Station, University of Puerto Rico, Rio Piedras, P.R. The author wishes to extend his most sincere appreciation to the Food Technology Staff members who aided in the chemical analyses as well as in the organoleptic appraisals of the dehydrated pigeonpeas.

2 Italic numbers in parentheses refer to Literature Cited, p. 180-1. 
Laboratory. He stated that starch content, alcohol-insoluble solids, specific gravity, percentage of moisture, and flotation characteristics have been definitely established as adequate indices for the evaluation of pigeonpea maturity.

Litwiller (2) reported that prefreezing was essential to the dehydration process of Blue Lake green beans since it decreased the final moisture level of the dried beans and increased the rehydration at least 20 percent. Hand et al. (3) found that slitting the seed with a mechanical peacoat slitter prior to rehydration facilitated the drying process and improved the quality of the rehydrated product. Talburt and Legult (4) stated that dehydrofrozen peas were equal to frozen peas in quality. Rahman (5) reported that pretreatment with sodium hydroxide improved the quality of the dehydrated peas. Cruess (6) reported that dehydration intensifies any toughness that beans may originally possess. Dawson et al. (7) stated that the quality of the dehydrated product was improved by dipping light-colored fruits and vegetables, such as apples and cauliflower, into solutions of sodium sulfite and sodium bicarbonate before rehydration. Blair (8) pointed out in the Blair process that dipping the peas in a 2-percent solution of sodium carbonate is an important step in the protection of their natural green color. Gieseker (9) developed a method of preserving the color of canned green vegetables which consists of soaking them in a dilute solution of ammonium hydroxide before canning. Moyer (10) said that dehydrated vegetables, in general, should be added directly to boiling water. He concluded that vegetables not soaked at all were the most palatable, and rated those soaked longest as soggy.

\section{MATERIALS AND PROCEDURES}

\section{PROCESSING}

Pigeonpeas (Cajan cajan L) (called "gandules" or "gandures" locally) of the variety Kaki were picked, cleaned, and then blanched at $190^{\circ} \mathrm{F}$. for 5 minutes in the pilot plant of the Food Technology Laboratory of the Agricultural Experiment Station. Some of the pigeonpeas were frozen to be used for further studies, especially at times when the fresh product is not available.

Four lots of pigeonpeas of equal weight were used in this study. The moisture content was 73.83 percent in two lots and 71.65 in the others. Two lots with different moisture contents were placed individually in 10-gallon glass jars, and a solution of 0.2-percent sodium hydroxide was added until all the pigeonpeas were completely submerged. The other two lots were kept in the cold room to avoid undesirable changes that might occur at room temperature while awaiting soaking of the first two lots. The soaking time was 4 hours. Upon the completion of the soaking treatments, the pigeonpeas were 
transferred into perforated trays $30 \times 20 \times 2$ inches in size and tapwater was added to wash out the residues of the sodium hydroxide. The pigeonpeas were drained for 10 minutes and then weighed.

\section{DEHYDRATION}

The four trays were placed in the Proctor and Schwartz cabinet dehydrator at the same time. The dry-bulb temperature was set at $200^{\circ} \mathrm{F}$. using the cross-circulation airflow, and after 1 hour it was reduced to $150^{\circ} \mathrm{F}$. for the rest of the dehydration period, which was 3 hours. The wet-bulb temperature was set at $100^{\circ} \mathrm{F}$. all the time. The dehydrated peas were weighed and then placed in polyethylene bags.

\section{RECONSTITUTION}

Dehydrated peas were reconstituted by adding $250 \mathrm{ml}$. of water to each $100 \mathrm{gm}$. of dehydrated peas and heating. After boiling they were allowed to simmer for different lengths of time ranging from 10 to 90 minutes. The pigeonpeas were drained for 10 minutes and weighed. The percentage of rehydration was computed by using the following equation:

$$
\frac{A \times C 100}{B \times D}=\text { percent rehydration. }
$$

Where $A=$ moisture-free weight of $100 \mathrm{gm}$. of fresh pigeonpeas; $B=$ moisture-free weight of dehydrated pigeonpeas; $C=$ increase in weight of dehydrated peas due to rehydration; $D=$ percentage moisture in the fresh peas.

Five hundred dehydrated pigeonpeas were taken at random from each lot. The pigeonpeas with cracked or broken seedcoats were counted, the degree of cracking or breakage being recorded as to whether it affected less of more than half of the surface of the seed.

\section{ORGANOLEPTIC APPRAISALS}

A flavor-difference test was conducted in which two samples, one of treated and the other of untreated rehydrated pigeonpeas, were presented to a panel of experienced tasters in order to judge the difference in color, texture, and flavor. The tasters were seated in air-conditioned taste-booths under red light in order to mask the natural color of the pigeonpeas while scoring the flavor. The samples were moved out of the booth in order to score the color under natural light. In the scoring ballots the following questions were presented: Is there any difference and, if so, which sample do you consider has better color, flavor, and texture?

A preliminary flavor-acceptance test was also conducted under the conditions described above by using the Hedonic Scale in which 9 points were 
given to the highest score indicating "like extremely" to 1 point for the lowest score indicating "dislike extremely". The data were analyzed statistically. The dehydrated pigenonpeas were also compared with canned pigeonpeas purchased from the local market which had been processed in Puerto Rico. All the pigeonpeas were presented to the tasters after being cooked with rice which constitutes a very popular dish in Puerto Rico. Therefore, a true picture might be obtained for the future consumption of this product.

TABLE 1.-Moisture of dehydrated pigeonpeas as affected by chemical pretreatment

\begin{tabular}{|c|c|c|c|c|}
\hline \multirow[t]{2}{*}{ Item } & \multicolumn{2}{|c|}{$\begin{array}{c}\text { Pigeonpeas soaked } \\
\text { in 0.2-percent solu- } \\
\text { tion of sodium } \\
\text { hydroxide for } 4 \\
\text { hours }\end{array}$} & \multicolumn{2}{|c|}{$\begin{array}{l}\text { Untreated } \\
\text { pigeonpeas }\end{array}$} \\
\hline & Sample 1 & Sample 2 & Sample 1 & Sample 2 \\
\hline Moisture as percentage of fresh peas & 73.83 & 71.65 & 73.83 & 71.65 \\
\hline $\begin{array}{l}\text { Weight in grams of fresh pigeonpeas before dehydra- } \\
\text { tion }\end{array}$ & 7,710 & 9,072 & 7,710 & 9,072 \\
\hline Weight in grams gained in soaking & 340 & 453 & - & - \\
\hline Weight in grams of pigeonpeas after rehydration & 1,890 & 2,800 & 2,007 & 2,920 \\
\hline Moisture as percentage of dehydrated pigeonpeas & 4.82 & 5.23 & 4.96 & 5.51 \\
\hline $\begin{array}{l}\text { Weight in grams of } 100 \mathrm{gm} \text {. of dehydrated peas after } \\
\text { rehydration }\end{array}$ & 360 & 320 & 338 & 292 \\
\hline Percentage rehydration & 96.82 & 91.60 & 89.00 & 80.40 \\
\hline $\begin{array}{l}\text { Gain in weight in grams, caused by soaking in } 0.2- \\
\text { percent sodium hydroxide for } 4 \text { hours }\end{array}$ & 340.0 & 450.0 & - & - \\
\hline
\end{tabular}

The texture of the reconstituted pigeonpeas was determined by means of the shear press. The color was determined by means of the Hunter Color and Color Difference Meter.

\section{ChEMICAL ANALYSES}

The moisture content of the pigeonpeas was determined by means of drying in the vacuum oven. The protein was determined by the Kjeldahl method. The starch, total sugars, reducing sugars, and alcohol-insoluble solids were determined by the A.O.A.C. methods (11). All the analyses were made in duplicate and then averaged.

\section{RESULTS AND DISCUSSION}

The results of the moisture determination on the dehydrated pigeonpeas, shown in table 1 , indicate that the pigeonpeas which were soaked for 4 hours in 0.2-percent solution of sodium hydroxide contained somewhat less 
moisture than the untreated ones, regardless of their stage of maturity. However, the treated pigeonpeas gained weight from 4 to 6 percent during the soaking treatment; therefore more moisture was evaporated from them than from the untreated ones. This suggests that some changes, whether physical or chemical, might have occurred that made the pigeonpeas lose or absorb moisture easier and faster.

As indicated in table 2, more treated than untreated peas had broken seedcoats. This might have contributed to the acceleration of dehydration as well as rehydration.

\section{RECONSTITUTION}

The results shown in table 3 and figure 1 , indicate that the treated pigeonpeas absorbed more moisture than the untreated ones at any length of rehydration time. The maximum weight for both treated and untreated

TABLE 2.-The degree of breakage in the seedcoats of 500 dehydrated pigeonpeas as affected by chemical pretreatment

\begin{tabular}{|c|c|c|c|c|c|c|c|c|c|}
\hline \multirow{2}{*}{ Treatment } & \multicolumn{3}{|c|}{$\begin{array}{l}\text { Seed without broken } \\
\text { seedcoats }\end{array}$} & \multicolumn{3}{|c|}{$\begin{array}{l}\text { Seed with less than half } \\
\text { the seedcoats broken }\end{array}$} & \multicolumn{3}{|c|}{$\begin{array}{l}\text { Seed with more than half } \\
\text { the seedcoats broken }\end{array}$} \\
\hline & Range & $\begin{array}{c}\text { Aver- } \\
\text { age }\end{array}$ & $\begin{array}{l}\text { Per- } \\
\text { cent }\end{array}$ & Range & $\begin{array}{c}\text { Aver- } \\
\text { age }\end{array}$ & Percent & Range & $\begin{array}{c}\text { Aver- } \\
\text { age }\end{array}$ & Percent \\
\hline $\begin{array}{l}\text { Seed soaked in } 0.2 \text {-per- } \\
\text { cent sodium hydroxide } \\
\text { for } 4 \text { hours }\end{array}$ & - & - & $\mathbf{0}$ & $10-21$ & 16 & 3.2 & $479-490$ & 484 & 96.8 \\
\hline Untreated seed & 41.59 & 50 & 10 & $68-93$ & 82 & 16.4 & $357-382$ & 368 & 73.6 \\
\hline
\end{tabular}

pigeonpeas was attained after 1 hour of simmering; it then remained almost constant up to 90 minutes. Here the treated pigeonpeas began to mash; the untreated pigeonpeas began to mash 10 minutes after the treated ones.

\section{CHEMICAL ANALYSIS}

The results of the chemical analyses obtained are shown in table 4 . The protein contents are almost the same in both the treated and the untreated pigeonpeas, whereas the treated pigeonpeas contained more starch and less total sugars than the untreated ones. However, when adding the contents of the starch and the total sugars together, forming the major constituents of carbohydrates, the results indicate a drift of increment in the treated ones, as shown at the bottom of table 4 . Histochemical research should be conducted in order to obtain sufficient data to explain these findings.

OBJECTIVE TEST FOR COLOR AND TEXTURE

The values of the shear press shown in table 5 indicate that a trend towards difference in the texture of the treated and the untreated pigeonpeas 
TABLE 3.-The weight in grams of $100 \mathrm{gm}$. of treated and untreated dehydrated pigeonpeas which were boiled and then simmered for different lengths of time

\begin{tabular}{|c|c|c|c|c|c|c|}
\hline \multirow{2}{*}{$\underset{\text { (minutes) }}{\text { Time simmered }}$} & \multicolumn{2}{|c|}{$\begin{array}{l}\text { Weight of rehydrated treated } \\
\text { pigeonpeas }\end{array}$} & \multicolumn{2}{|c|}{$\begin{array}{l}\text { Weight of rehydrated } \\
\text { untreated pigeonpeas }\end{array}$} & \multicolumn{2}{|c|}{$\begin{array}{c}\text { Increment in weight due to } \\
\text { treatment }\end{array}$} \\
\hline & $\begin{array}{c}\text { Original } \\
\text { moisture } \\
\text { content } 73.83 \\
\text { percent }\end{array}$ & $\begin{array}{c}\text { Original } \\
\text { moisture } \\
\text { content } 71.65 \\
\text { percent }\end{array}$ & $\begin{array}{c}\text { Original } \\
\text { moisture } \\
\text { contents } 73.83 \\
\text { percent }\end{array}$ & $\begin{array}{c}\text { Original } \\
\text { moisture } \\
\text { content } 71.65 \\
\text { percent }\end{array}$ & $\begin{array}{c}\text { Original } \\
\text { moisture } \\
\text { content } 73.83 \\
\text { percent }\end{array}$ & $\begin{array}{c}\text { Original } \\
\text { moisture } \\
\text { content } 71.65 \\
\text { percent }\end{array}$ \\
\hline 10 & 299 & 294 & 274 & 270 & 25 & 24 \\
\hline 15 & 308 & 303 & 279 & 276 & 29 & 27 \\
\hline 20 & 316 & 314 & 288 & 287 & 28 & 27 \\
\hline 25 & 322 & 320 & 292 & 290 & 30 & 30 \\
\hline 30 & 332 & 329 & 298 & 292 & 34 & 37 \\
\hline 40 & 339 & 334 & 300 & 298 & 39 & 36 \\
\hline 50 & 352 & 349 & 312 & 310 & 40 & 39 \\
\hline 60 & 359 & 353 & 319 & 313 & 40 & 40 \\
\hline 70 & 366 & 358 & 322 & 319 & 44 & 39 \\
\hline 80 & 365 & 357 & 323 & 317 & 42 & 40 \\
\hline 90 & 366 & 358 & 323 & 318 & 43 & 40 \\
\hline
\end{tabular}

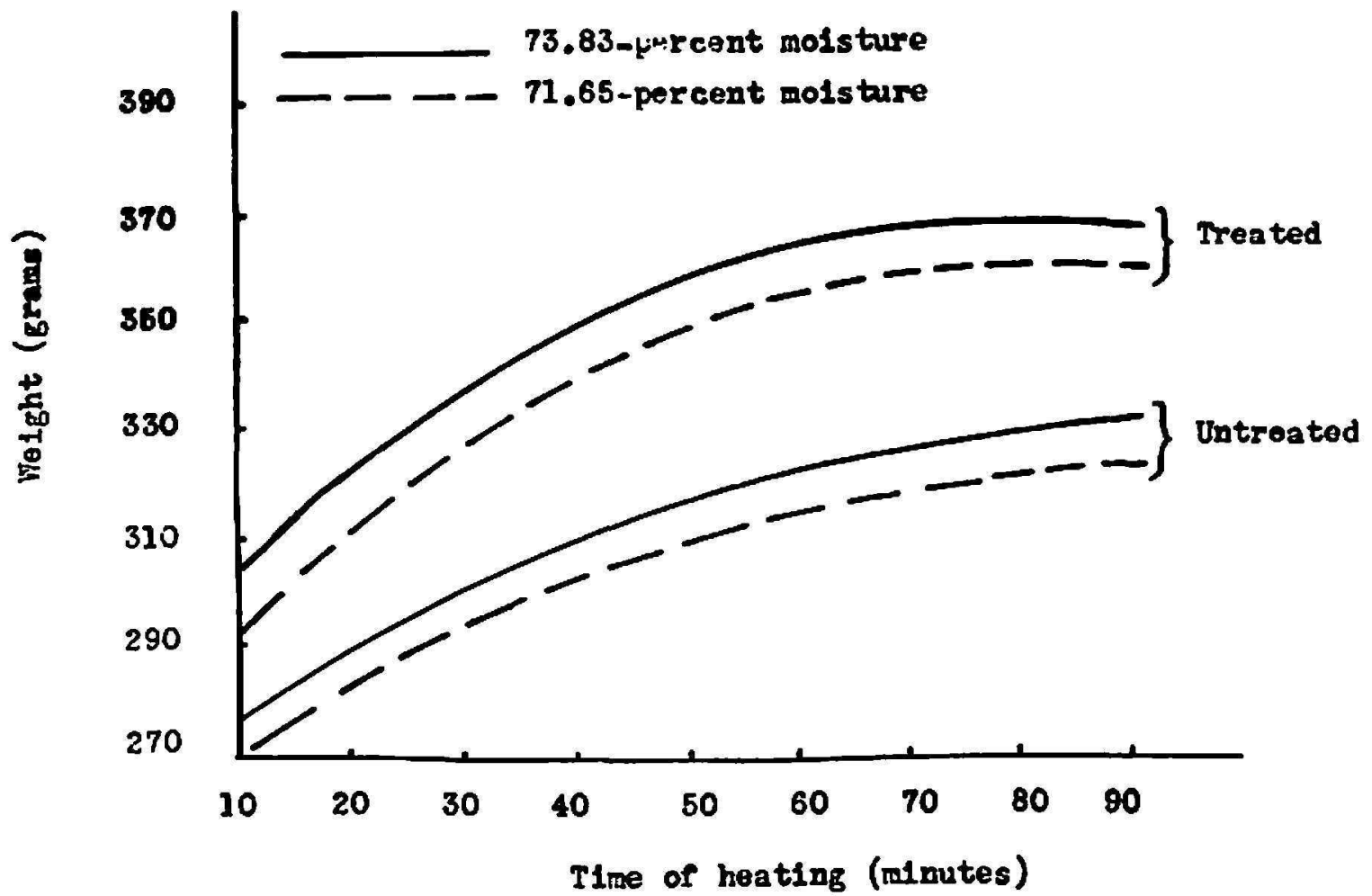

Fig. 1.-The increment in weight upon the rehydration of $100 \mathrm{gm}$. of treated and untreated pigeonpeas at different lengths of time. 
exists. This corresponds with the scores of the majority of the judges during the organoleptic appraisals. The results for the color as determined by the Hunter Color and Color Difference Meter show that the treated pigeonpeas possess a rather greener color than the untreated ones. This also confirms

TABLE 4.-Chemical analyses (percentage) of the treated and untrealed dehydrated pigeonpeas of different moisture content

\begin{tabular}{|c|c|c|c|c|c|c|c|c|}
\hline \multirow{3}{*}{ Constituent } & \multicolumn{4}{|c|}{ Treated } & \multicolumn{4}{|c|}{ Untreated } \\
\hline & \multicolumn{2}{|c|}{$\begin{array}{l}\text { Pigeonpeas with } \\
73.83 \text { percent } \\
\text { original moisture }\end{array}$} & \multicolumn{2}{|c|}{$\begin{array}{l}\text { Pigeonpeas with } \\
71,65 \text { percent } \\
\text { original moisture }\end{array}$} & \multicolumn{2}{|c|}{$\begin{array}{l}\text { Pigeonpeas with } \\
73,83 \text { percent } \\
\text { original moisture }\end{array}$} & \multicolumn{2}{|c|}{$\begin{array}{l}\text { Pigeonpeas with } \\
71.65 \text { percent } \\
\text { original moisture }\end{array}$} \\
\hline & Wet basis & Dry basis & Wet basis & Dry basis & Wet basi & Dry basis & Wet basis & Dry basi \\
\hline & 20.59 & 21.63 & 19.67 & 20.70 & 20.57 & 21.70 & 19.28 & 20.40 \\
\hline Total sugars & 1.68 & 1.77 & 2.22 & 2.33 & 2.42 & 2.55 & 2.34 & 2.47 \\
\hline Reducing sugars & $\mathbf{0}$ & $\mathbf{0}$ & $\mathbf{0}$ & 0 & 0 & 0 & 0 & 0 \\
\hline Starch & 53.46 & 56.16 & 58.31 & 61.35 & 50.76 & 53.56 & 55.69 & 58.93 \\
\hline $\begin{array}{l}\text { Alcohol-insoluble sol- } \\
\text { ids }\end{array}$ & 82.95 & 87.15 & 83.02 & 87.35 & 78.66 & 83.00 & 83.37 & 88.25 \\
\hline Starch + total sugars & 55.14 & 57.93 & 60.53 & 63.68 & 53.18 & 56.11 & 58.03 & 61.40 \\
\hline
\end{tabular}

TABLE 5.-Values of the shear press and Hunter Color and Color Difference Meter for the rehydrated treated and untreated pigeonpeas of different moisture content

\begin{tabular}{|c|c|c|c|c|}
\hline \multirow[b]{2}{*}{ Value } & \multicolumn{2}{|c|}{ Treated pigeonpeas } & \multicolumn{2}{|c|}{ Untreated pigeonpeas } \\
\hline & $\begin{array}{l}\text { Rehy- } \\
\text { drated } \\
\text { peas with } \\
73.83 \text { per- } \\
\text { cent ori- } \\
\text { ginal } \\
\text { moisture }\end{array}$ & $\begin{array}{c}\text { Rehy- } \\
\text { drated } \\
\text { peas with } \\
71.65 \text { per- } \\
\text { cent ori- } \\
\text { ginal } \\
\text { moisture }\end{array}$ & $\begin{array}{c}\text { Rehy- } \\
\text { drated } \\
\text { peas with } \\
73.83 \text { per- } \\
\text { cent ori- } \\
\text { ginal } \\
\text { moisture }\end{array}$ & $\begin{array}{c}\text { Rehy- } \\
\text { drated } \\
\text { peas with } \\
\text { 71.65 per- } \\
\text { cent ori- } \\
\text { ginal } \\
\text { moisture }\end{array}$ \\
\hline Shear-press & 360 & 560 & 520 & 760 \\
\hline \multicolumn{5}{|l|}{ Hunter Color and Color Difference Meter } \\
\hline$R d$ & 7.2 & 10.2 & 9.4 & 12.4 \\
\hline$a$ & -2.5 & -2.4 & +.3 & -.4 \\
\hline$b$ & +13.3 & +13.8 & +13.2 & +14.5 \\
\hline
\end{tabular}

the scores by the majority of the tasters in judging the difference in the color.

\section{ORGANOLEPTIC APPRAISAL}

The results shown in table 6 indicate that a difference in the color and texture was definitely established, whereas no significant difference was shown in the flavor. This indicates that the treatment did not affect the 
flavor as much as it did the color and texture. The majority of the judges preferred the color and texture of the treated pigeonpeas, but no significant difference could be established statistically, as shown in table 7. No preference was shown as to flavor as indicated in table 8.

TABLE 6. -The scores of 10 judges indicaling the difference in color, texture, and flavor between the treated and untreated pigeonpeas

\begin{tabular}{|c|c|c|c|c|c|c|}
\hline \multirow{2}{*}{ Characteristic } & \multicolumn{2}{|c|}{ Is there any difference? } & \multicolumn{3}{|c|}{$\begin{array}{l}\text { Which one do you consider has better } \\
\text { color, texture, or favor? }\end{array}$} & \multirow{2}{*}{$\begin{array}{l}\text { Minimum num- } \\
\text { ber of tasters } \\
\text { required to have } \\
\text { correct decision } \\
\text { in paired tests } \\
\text { for } 1 \text {-percent } \\
\text { levelsignificance }\end{array}$} \\
\hline & \begin{tabular}{|l|} 
Judges \\
indicating yes'
\end{tabular} & $\underset{\text { no }}{\text { Judges }}$ & Treated & Untreated & $\begin{array}{c}\text { No } \\
\text { difference }\end{array}$ & \\
\hline Color & $10^{*}$ & 0 & 7 & 3 & 0 & 10 \\
\hline Texture & $10^{*}$ & 0 & 6 & 4 & 0 & 10 \\
\hline Flavor & 8 & 2 & 4 & 4 & 2 & 10 \\
\hline
\end{tabular}

1 * Significant difference at the 1-percent level.

TABLE 7.-The analysis of variance of the scores of 15 tasters, indicating the degree of acceptability of the treated and untreated dehydrated pigeonpeas when cooked with rice

\begin{tabular}{l|c|c|c|c|c}
\hline \multicolumn{1}{c|}{ Source of variance } & $\begin{array}{c}\text { Degrees of } \\
\text { freedom }\end{array}$ & $\begin{array}{c}\text { Sum of } \\
\text { squares }\end{array}$ & $\begin{array}{c}\text { Mean } \\
\text { squares }\end{array}$ & $F$ & $\begin{array}{l}F \text { at 5-per- } \\
\text { cent level }\end{array}$ \\
\hline $\begin{array}{c}\text { Among treatments } \\
\text { Among scores of tasters }\end{array}$ & $\begin{aligned} 1 \\
28\end{aligned}$ & $\begin{array}{c}0.3 \\
17.1\end{array}$ & $\begin{array}{c}0.3 \\
.61\end{array}$ & 0.491 & 4.21 \\
Total & 29 & 17.4 & & & \\
\hline
\end{tabular}

TABLE 8. -The analysis of variance of 10 tasters, indicating the degree of acceplance of the treated, untreated, and canned pigeonpeas when cooked with rice

\begin{tabular}{l|c|c|c|c|c}
\hline \multicolumn{1}{c|}{ Source of variance } & $\begin{array}{c}\text { Degrees of } \\
\text { freedom }\end{array}$ & $\begin{array}{c}\text { Sum of } \\
\text { squares }\end{array}$ & $\begin{array}{c}\text { Mean } \\
\text { squares }\end{array}$ & $F$ & $\begin{array}{l}F \text { at 5-per- } \\
\text { cent level }\end{array}$ \\
\hline Among treatments & 2 & 1.27 & 0.63 & 0.50 & 3.53 \\
Among scores of tasters & 27 & 33.70 & 1.24 & & \\
Total & 29 & 34.97 & & & \\
\hline
\end{tabular}

\section{SUMMARY}

A study was undertaken to determine the effect of soaking pigeonpeas in a 0.2-percent solution of sodium hydroxide for 4 hours before dehydration, upon the quality of the dehydrated product. The results showed that:

1. The treated pigeonpeas contained less moisture, but had a higher 
rehydration ratio upon reconstitution than the untreated ones, regardless of their stage of maturity.

2. The percentage of breakage in the seedcoats of the treated pigeonpeas was higher than that for the untreated ones.

3. The protein content was almost the same in the treated and untreated peas, but the treated pigeonpeas were higher in starch and lower in total sugars than the untreated ones.

4. The organoleptic tests established a definite difference in color and texture between the products, but no difference in flavor. The two products were equally acceptable to the taste panel. Similar results were obtained when comparing both treated and untreated dehydrated pigeonpeas with the canned ones.

5. The shear-press and the Hunter Color and Color Difference Meter tests indicated that the treated pigeonpeas were more tender and greener than the untreated ones.

\section{RESUMEN}

Se llevó a cabo un estudio para determinar los efectos que ha de tener sobre la calidad de los gandures secos el empaparlos en una solución de hidróxido de sodio al 0.2 por ciento durante cuatro horas antes de deshidratarlos. Los resultados demonstraron lo siguiente:

1. La humedad de las gandures tratados fue más baja que en los que no se trataron. $\mathrm{Al}$ reconstituirse, absorbieron más agua irrespectivamente de su grado de madurez.

2. El porcentaje de cutícula rota fue mayor en los gandures tratados que en los que no se trataron.

3. El contenido de proteínas no fue alterado por el tratamiento. Los gandures tratados contenían mas almidón y menos azúcares totales que los que no se trataron.

4. Las pruebas de catado establecieron una destacada diferencia en cuanto a color y textura de ambos productos, aunque no se notó diferencia alguna en el sabor. Los dos productos tuvieron el mismo grado de aceptación por el panel de catado. Cuando se compararon ambos productos deshidratados con los enlatados se obtuvieron resultados similares.

5. Las pruebas de dureza, color y diferencia de color demonstraron que los gandures tratados quedaron más tiernos y mas verdes que los que no se trataron.

\section{LITERATURE CITED}

1. Sánchez-Nieva, F., The Canning of Pigeonpeas, Master Plans, Department of Food Technology, Agr. Exp. Sta., Project Hatch 70, fiscal year 1959-60.

2. Litwiller, E. M., and Pettit, L. A., Dehydrated Blue Lake green beans, Food Tech. 11 229-31, 1957. 
3. Hand, D. B., Moyer, J. C., and Wagenknecht, A. C., Effect of drying conditions on moisture retention and density of dehydrated peas, Food Tech. $9222,1955$.

4. Talburt, W. F., and Legult, R. R., Dehydro-frozen peas, Food Tech. 4 286-91, 1950.

5. Rahman, A. R., Histological and Histochemical Investigations of the Effect of Certain Chemicals Upon the Quality of Dehydrated Peas, Ph.D. thesis, Oregon State College, Corvallis, Oreg., 1956.

6. Cruess, W. V., Commercial Fruit and Vegetable Products, 3d ed. p. 906, McGrawHill, New York, N.Y., 1948.

7. Dawson, E. M., Batchelder, E. L., and Taube, K. R., Flavor, Texture, Color, and Ascorbic Acid Content of Home Dehydrated Vegetables and Fruits, p. 68, USDA Tech. Bul. 997, Washington, U.S. Government Printing Office, 1950.

8. Blair, J. S. and Ayres, T. B., Protection of natural green color pigment in the canning of peas, Ind. Eng. Chem. 36 85, 1943.

9. Gieseker, L. F., Preserving the Color of Canned Peas, U.S. Patent 2,473,747, June 21, 1949.

10. Moyer, J. C., Nutritive value of dehydrated vegetables, J. Amer. Diet. Assn. 19 13-7, 1943.

11. Assn. of Agr. Chem., Official Methods of Analysis, Washington, D.C., 8th ed., 1955.

12. Lloréns, Antonio A., Olivieri, José A., and Ríos, J. M., Production and Marketing of Pigeon Peas in Puerto Rico, E. \& R. S. 32, Univ. P.R., Agr. Exp. Sta., 1956.

13. Von Loeseke, M. W., p. 98-102, Drying and Dehydration of Foods, Reinhold, New York, N.Y., 1955.

14. Statistical Yearbook 1958, Bureau of Economics and Statistics, Puerto Rico Planning Board. 